\title{
PENGARUH KOMPETENSI DAN KUALITAS PETUGAS KESEHATAN TERHADAP KEPUASAN PASIEN RAWAT JALAN DI PUSKESMAS SEI AGUL MEDAN
}

\author{
Suhartina $^{1 *}$, Tarianna Ginting ${ }^{2}$, Tan Suyono ${ }^{1}$, Wella Adenata Sipayung ${ }^{2}$ \\ ${ }^{1}$ Fakultas Kedokteran Universitas Prima Indonesia \\ ${ }^{2}$ Fakultas Kesehatan Masyarakat Universitas Prima Indonesia \\ *email: darmaditina@gmail.com
}

\begin{abstract}
ABSTRAK
Permasalahan kinerja yang timbul di Puskesmas Sei Agul tidak terlepas dari kompetensi dan kualitas pelayanan yang menjadi modal dalam mempertahankan roda organisasinya. Masyarakat umumnya pasti memiliki keinginan mendapat pelayanan yang berkualitas. Permasalahan dalam penelitian ini adalah apakah kompetensi dan kualitas pelayanan yang terdiri dari kehandalan, daya tanggap, jaminan, empati dan bukti fisik berpengaruh positif dan signifikan terhadap kepuasan pasien. Tujuan penelitian ini untuk mengetahui seberapa besar pengaruh kompetensi dan kualitas petugas kesehatan terhadap tingkat kepuasan pasien rawat jalan di Puskesmas Sei Agul. Adapun penelitian ini adalah survei analitik dengan menggunakan desain penelitian cross sectional dengan sampel 96 orang. Teknik pengambilan sampel yang digunakan adalah Purposive Sampling. Hasil penelitian ini menunjukan bahwa nilai p-value antara kompetensi $(0,015)$, kehandalan $(0,043)$, daya tanggap $(0,005)$, jaminan $(0,109)$, empati $(0,000)$, bukti fisik $(0,002)$. Dari hasil analisis regresi berganda memperlihatkan bahwa kompetensi dan empati berpengaruh signifikan secara bersamasama terhadap kepuasan pasien. Namun yang paling berpengaruh terhadap kepuasan pasien ialah Empati $(0,000)$ dibandingkan dengan kompetensi $(0,013)$. Kesimpulan dari penelitian ini adalah terdapat pengaruh yang bermakna antara kompetensi, kehandalan, daya tanggap, empati dan bukti fisik terhadap kepuasan pasien, sedangkanjaminan tidak berpengaruh terhadap kepuasan pasien. Dan dari hasil uji regresi empati yang paling mempengaruhi kepuasan pasien.
\end{abstract}

Kata Kunci : Kompetensi, Kualitas Petugas Kesehatan, Kepuasan Pasien Rawat Jalan

\begin{abstract}
Performance problems that arise in Sei Agul Health Center are inseparable from the competence and quality of service that is the capital in maintaining the wheels of the organization. The general public must have the desire to get quality services. The purpose of this study was to determine how much influence the competence and quality of health workers on the level of outpatient satisfaction at the Sei Agul Health Center. The study was an analytic survey using a cross sectional study design with a sample of 96 people. The sampling technique used is purposive sampling. The results of this study indicate that the $p$-value between competence (0.015), reliability (0.043), responsiveness $(0.005)$, guarantee (0.109), empathy $(0,000)$, physical evidence (0.002). From the results of multiple regression analysis shows that competence and empathy have a significant effect together on patient satisfaction. But the most influential on patient satisfaction is Empathy $(0,000)$ compared to competence $(0.013)$. The conclusion of this study is that there is a significant influence between competence, reliability, responsiveness, empathy and physical evidence on patient satisfaction, whereas guarantees do not affect patient satisfaction. And the results of the empathy regression test that most influence patient satisfaction.
\end{abstract}

Keywords: Competence, Quality of Health Officers, outpatient satisfaction

\section{PENDAHULUAN}

Kompetensi sebagai karakteristik dasar dari seseorang yang memungkinkan mengeluarkan kinerja superior dalam pekerjaannya (Hastuti, 2018). Kompetensi perlu dipahami oleh petugas kesehatan dalam melaksanakan tugas dan wewenangnya. Kualitas memberikan suatu dorongan kepada pasien untuk menjalin ikatan hubungan yang kuat dengan puskesmas
(Radito,2014). Pelayanan yang memuaskan dan berkualitas akan membentuk loyalitas pasien.

Hasil penelitian Fahlevi (2017) menunjukkan bahwa ada pengaruh antara pengetahuan petugas kesehatan terhadap kinerja pelayanan kesehatan di Puskesmas Peureumeue Kecamatan Kaway XVI Kabupaten Aceh Barat, di mana menunjukkan bahwa berpengetahuan baik dengan kategori kinerja baik sebanyak $75,8 \%$, 
berpengetahuan kurang baik dengan kategori kinerja kurang baik sebanyak 52,4\%. Hasil penelitian yang dilakukan Eninurkhayatun dkk (2017) menunjukkan bahwa tingkat kesesuaian rata-rata keseluruhan dimensi kualitas pelayanan rawat jalan yaitu $79,70 \%$. Dimensi pelayanan yang memiliki tingkat kesesuaian dibawah ratarata antara lain dimensi kehandalan sebanyak $79,36 \%$, dimensi daya tanggap sebanyak $77,00 \%$, dan dimensi jaminan sebanyak $79,44 \%$.

Pemanfaatan fasilitas kesehatan oleh masyarakat dapat dilihat dari jumlah kunjungan terhadap fasilitas kesehatan yang ada. Terlihat jelas bahwa terjadi peningkatan jumlah kunjungan pasien yaitu pada tahun 2014 kunjungan pasien rawat jalan sebanyak 876.686 jiwa, tahun 2015 sebanyak 947.987 jiwa, dan tahun 2016 sebanyak 1.150.703 jiwa (Profil Kesehatan Kota Medan, 2016).

Sedangkan berdasarkan Profil Puskesmas Sei Agul data kunjungan pasien rawat jalan di Puskesmas Sei Agul dalam 3 tahun terakhir menunjukan bahwa angka kunjungan pasien rawat jalan menurun yaitu pada tahun 2016 sebanyak 28.797 jiwa, tahun 2017 sebanyak 28.219 jiwa, tahun 2018 sebanyak 27.732 jiwa. Terjadinya Penurunan jumlah pasien perlu dicari penyebabnya, apakah karena kualitas pelayanan yang diberikan kurang memuaskan, seperti fasilitas yang mungkin kurang memadai atau karena lambatnya penanganan medis terhadap pasien atau mungkin dari segi pelayanan tenaga medis maupun non medis, sehingga pasien tidak mau berobat di Puskesmas. Banyak faktor yang mempengaruhi kepuasan pasien yang bisa berdampak pada kepercayaan pasien akan layanan yang diberikan oleh Puskesmas Sei Agul. Dari paparan di atas maka peneliti tertarik melakukan penelitian tentang pengaruh kompetensi dan kualitas pelayanan petugas Puskesmas terhadap kepuasan pasien di Puskesmas Sei Agul Medan.

\section{METODE}

Penelitian ini menggunakan metode Survei analitik yaitu untuk mengetahui pengaruh kompetensi dan kualitas petugas kesehatan terhadap kepuasan pasien rawat jalan di Puskesmas SeiAgul Medan. Dengan menggunakan rancangan Cross-Sectional. Penelitian ini dilaksanakan di Puskesmas SeiAgul Medan pada bulan Mei 2019. Populasi dalam penelitian ini adalah semua pasien rawat jalan di Puskesmas Sei Agul pada bulan September 2018 sebanyak 2.167 pasien. Jumlah sampel dalam penelitian ini adalah 96 pasien rawat jalan.Teknik pengambilan sampel yang digunakan dalam penelitian ini adalah purposive sampling yang ditentukan berdasarkan kriteria inklusi dan eksklusi.

Data primer pada penelitian ini diperoleh dari kuisoner dengan responden yaitu pasien rawat jalan di Puskesmas Sei Agul. Data sekunder pada penelitian ini berupa jumlah pasien rawat jalan Puskesmas SeiAgul yang diperoleh peneliti serta refrensi-refrensi yang mendukung dalam penelitian ini. Analisis menggunakan uji chi- square di mulai dari univariat dan bivariat dan multivariat.

\section{HASIL}

Berdasarkan tabel 1, Sampel yang $>7 x$ sebanyak 50 orang $(52,1 \%)$ dan lama berjumlah 96 responden terdapat 64 responden $(66,7 \%)$ dengan jenis kelamin perempuan dan 31 responden $(32,3 \%)$ dengan jenis kelamin laki- laki. $\mathrm{Hal}$ ini menunjukan bahwa sebagian besar responden didominasi oleh perempuan. Dilihat dari kelompok umur, menunjukan bahwa responden yang berumur 37-46 tahun sebanyak 29 orang $(30,2 \%)$ dan kelompok umur $27-36$ tahun sebanyak 10 orang (10,4\%). Hasil distribusi frekuensi lama berkunjung responden berkunjung $<7 x$ sebanyak 46 orang $(47,9 \%)$. Dari tingkat pendidikan sebagian besar pasien lebih dominan pendidikan SMA sebanyak 38 orang $(39,6 \%)$ dan pasien berlatar belakang pendidikan D-III masingmasing berjumlah 5 responden (5,2\%). Berdasarkan distribusi frekuensi pekerjaan responden menunjukan bahwa yang tidak bekerja sebanyak 50 orang $(52,1 \%)$ dan PNS berjumlah 5 orang $(5,2 \%)$. 
Tabel 1. Karakteristik Responden

\begin{tabular}{|c|c|c|c|}
\hline No & $\begin{array}{l}\text { Karakteristi } \\
\text { k }\end{array}$ & Jumlah & Persentase (\%) \\
\hline \multirow[t]{3}{*}{1} & Jenis Kelamin & & \\
\hline & $\begin{array}{l}\text { Laki-laki } \\
\text { Perempuan }\end{array}$ & $\begin{array}{l}31 \\
65\end{array}$ & $\begin{array}{l}32.3 \\
67.7\end{array}$ \\
\hline & Total & 96 & 100.0 \\
\hline \multirow[t]{8}{*}{2} & Umur & & \\
\hline & $17-26$ & 11 & 11.5 \\
\hline & $27-36$ & 10 & 10.4 \\
\hline & $37-46$ & 29 & 30.2 \\
\hline & $47-56$ & 16 & 16.7 \\
\hline & $57-66$ & 19 & 19.8 \\
\hline & $67-76$ & 11 & 11.5 \\
\hline & Total & 96 & 100.0 \\
\hline \multirow[t]{4}{*}{3} & Lama Berkunjung & & \\
\hline & $<7 x$ & 46 & 47.9 \\
\hline & $>7 x$ & 50 & 52.1 \\
\hline & Total & 96 & 100.0 \\
\hline \multirow[t]{7}{*}{4} & Pendidikan & & \\
\hline & SD & 19 & 19.8 \\
\hline & SMP & 13 & 13.5 \\
\hline & SMA & 38 & 39.6 \\
\hline & D-III & 5 & 5.2 \\
\hline & S1 & 21 & 21.9 \\
\hline & Total & 96 & 100.0 \\
\hline \multirow[t]{7}{*}{5} & Pekerjaan & & \\
\hline & Tidak ada & 50 & 52.1 \\
\hline & PNS & 10 & 10.4 \\
\hline & Wiraswasta & 23 & 24.0 \\
\hline & Pegawai & 8 & 8.3 \\
\hline & Pensiun & 5 & 5.2 \\
\hline & Total & 96 & 100.0 \\
\hline
\end{tabular}

Berdasarkan analisis univariat (Tabel 2), dapat dilihat bahwa persepsi responden mengenai kompetensi, mayoritas responden menjawab tidak baik yaitu 59 orang $(61,5 \%)$ dan menoritas responden menjawab baik 37 orang $(38,5 \%)$. Sedangkan dari segi kehandalan, mayoritas responden menjawab tidak baik yaitu 51 orang $(53,1 \%)$ dan minoritas menjawab baik 45 orang $(46,9 \%)$. Berdasarkan daya tanggap, mayoritas responden menjawab tidak baik yaitu sebanyak 53 orang $(55,2 \%)$ dan minoritas responden menjawabbaik 43 orang $(44,8 \%)$. Dari segi jaminan, mayoritas responden menjawab baik yaitu sebanyak 53 orang $(53,1 \%)$ dan minoritas responden menjawab tidak baik yaitu 43 orang (44,8\%). Sedangkan empati, mayoritas responden menjawab tidak baik yaitu 54 orang $(56,3 \%)$ dan minoritas responden menjawab baik yaitu 42 orang $(43,8 \%)$. Pada dimensi bukti fisik, mayoritas responden menjawab tidak baik yaitu sebanyak 52 orang $(54,2 \%)$ dan minoritasresponden menjawab baik yaitu 44 orang (45,8\%). Ditinjau dari kepuasan pasien, mayoritas responden menyatakan tidak puas sebanyak 50 orang $(52,1 \%)$, sedangkan minoritas responden menjawab puas yaitu 46 orang $(47,9 \%)$. 
Tabel 2. Distribusi Frekuensi Responden Berdasarkan Kompetensi, Pelayanan Kehandalan, Pelayanan Daya Tanggap, Pelayanan Jaminan, Pelayanan Empati,Pelayanan Bukti Fisik Terhadap Kepuasan Pasien Rawat Jalan

\begin{tabular}{|c|c|c|c|}
\hline No & Variabel & Jumlah (n) & Persentase (\%) \\
\hline \multirow[t]{4}{*}{1} & Kompetensi & & \\
\hline & Baik & 37 & 38.5 \\
\hline & Tidak Baik & 59 & 61.5 \\
\hline & Total & 96 & 100.0 \\
\hline \multirow[t]{4}{*}{2} & Kehandalan & & \\
\hline & Baik & 45 & 46.9 \\
\hline & Tidak Baik & 51 & 53.1 \\
\hline & Total & 96 & 100.0 \\
\hline \multirow[t]{4}{*}{3} & Daya Tanggap & & \\
\hline & Baik & 43 & 44,8 \\
\hline & Tidak Baik & 53 & 55,2 \\
\hline & Total & 96 & 100.0 \\
\hline \multirow[t]{4}{*}{4} & Jaminan & & \\
\hline & Baik & 53 & 55,2 \\
\hline & Tidak Baik & 43 & 44,8 \\
\hline & Total & 96 & 100.0 \\
\hline \multirow[t]{4}{*}{5} & Empati & & \\
\hline & Baik & 42 & 43.8 \\
\hline & Tidak Baik & 54 & 56.3 \\
\hline & Total & 96 & 100.0 \\
\hline \multirow[t]{4}{*}{6} & Bukti Fisik & & \\
\hline & Baik & 44 & 45.8 \\
\hline & Tidak Baik & 52 & 54.2 \\
\hline & Total & 96 & 100.0 \\
\hline \multirow[t]{4}{*}{7} & Kepuasan Pasien & & \\
\hline & Baik & 46 & 47.9 \\
\hline & Tidak Baik & 50 & 52.1 \\
\hline & Total & 96 & 100.0 \\
\hline
\end{tabular}

Pada tabel 3 diketahui bahwa dari 33 responden menilai kompetensi baik, mayoritas responden menyatakan puas sebanyak 23 orang $(69,7 \%)$ dan minoritas responden menjawab tidak puas yaitu 10 orang $(30,3 \%)$. Dari 63 responden menilai kompetensi tidak baik, mayoritas responden menjawab tidak puas sebanyak 23 orang $(36,5 \%)$ dan minoritas responden menyatakan puas puas yaitu 40 orang (63,5\%). Hasil analisis bivariat dengan menggunakan uji chi-square diperoleh nilai $\mathrm{p}$ value $=0,004$ ( $p$-value $<0,05$ ), artinya Ho ditolak, ini menunjukan bahwa ada pengaruh signifikan antara kompetensi terhadap kepuasan pasien rawat jalan di Puskesmas Sei Agul.

Dari 45 responden menilai kehandalan baik, mayoritas responden menjawab puas yaitu sebanyak 27 orang $(60,0 \%)$ dan minoritas responden menjawab tidak puas yaitu 18 orang (40,0\%). Dari 51 responden menilai kehandalan 
tidak baik, mayoritas responden menjawab tidak puas yaitu sebanyak 32 orang $(62,7 \%)$ dan minoritas responden petugas menjawab puas terhadap pelayanan yang diberikan sebanyak 19 orang $(37,3 \%)$. Hasil analisis bivariat dengan menggunakan uji chi-square diperoleh nilai $p$ value $=0,043(p$-value $<0,05)$, artinya Ho ditolak, ini menunjukan bahwa ada pengaruh signifikan antara kehandalan petugas kesehatan terhadap kepuasan pasien rawat jalan di Puskesmas Sei Agul.

Dari 43 responden yang menilai daya tanggap baik,mayoritas responden menjawab puas yaitu sebanyak 28 orang $(65,1 \%)$ dan minoritas responden menjawab tidak puas yaitu 15 orang $(34,9 \%)$. Dari 53 responden menilai daya tanggap tidak baik, mayoritas responden menjawab tidak puas yaitu sebanyak 35 orang $(66,0 \%)$ dan minoritas responden menjawab puas yaitu 18 orang (34,0\%). Hasil analisis bivariat dengan menggunakan uji chi-square diperoleh nilai $p$ - value $=0,005(p$-value $<0,05)$, artinya Ho ditolak, ini menunjukan bahwa ada pengaruh signifikan antara daya tanggap petugas kesehatan terhadap kepuasan pasien rawat jalan di Puskesmas Sei Agul.

Dari 53 responden menilai jaminan baik,mayoritas responden menjawab tidak puas yaitu sebanyak 32 orang $(60,4 \%)$ danminoritas responden menjawab puas yaitu 21 orang $(39,6 \%)$. Dari 43 responden menilai jaminan tidak baik, mayoritas responden menjawab puas yaitu sebanyak 25 orang $(58,1 \%)$ dan minoritas responden menjawab tidak puas yaitu 18 orang $(41,9 \%)$. Hasil analisis bivariat dengan menggunakan uji chi-square diperoleh nilai $p$ value $=0,109 \quad(p$-value $>0,05)$, artinya $\mathrm{Ho}$ diterima, ini menunjukan bahwa tidak ada pengaruh signifikan antara jaminan petugas kesehatan terhadap kepuasan pasien rawat jalan di Puskesmas Sei Agul.

Tabel 3. Hasil uji chi square

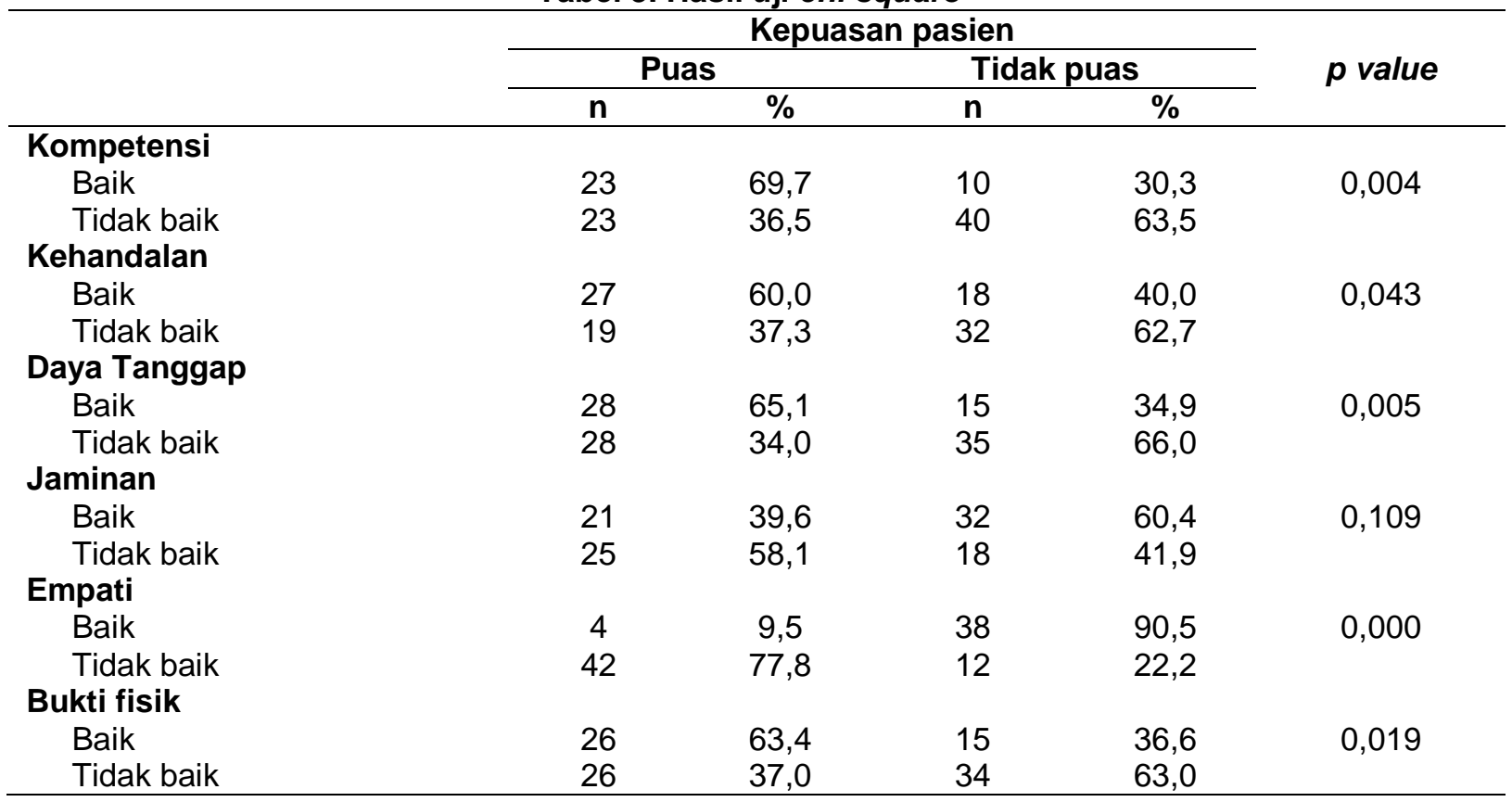

Dari 42 responden menilai empati baik, mayoritas responden menjawab tidak puas yaitu sebanyak 38 orang $(90,5 \%)$ dan minoritas responden menjawabpuas yaitu 4 orang $(9,5 \%)$. Dari 54 responden menilai empati tidak baik, mayoritas responden menjawab puas yaitu sebanyak 42 orang $(77,8 \%)$ danminoritas responden menjawab tidak puas yaitu 12 orang $(22,2 \%)$. Hasil analisis bivariat dengan menggunakan uji chi-square diperoleh nilai $\mathrm{p}$ value $=0,000(p$-value $<0,05)$, artinya Ho ditolak, ini menunjukan bahwa ada pengaruh signifikan antara empati petugas kesehatan terhadap kepuasan pasien rawat jalan di Puskesmas Sei 
Agul.

Dari 44 responden menilai bukti fisik baik, mayoritas responden menjawab tidak puas yaitu sebanyak 31 orang $(70,5 \%)$ dan minoritas responden menjawab puas yaitu 13 orang $(29,5 \%)$. Dari 52 responden menilai bukti fisik tidak baik, mayoritas responden menjawab puas yaitu sebanyak 33 orang $(63,5 \%)$ dan minoritas.

Berdasarkan hasil analisis regresi beganda, kompetensi tidak mempunyai pengaruh yang signifikan terhadap kepuasan pasien rawat jalan di Puskesmas Sei Agul. Berdasarkan hasil observasi, kompetensi tenaga kesehatan di Puskesmas Sei Agul cukup baik karena tenaga kesehatan dalam menanggapi pasien sangat ramah dan sopan sehingga pasien merasa lebih diperhatikan oleh tenaga kesehatannamun penelitian ini berbeda dengan penelitian yang dilakukan oleh Rensi (2019) yang menunjukan hasil analisis diperoleh nilai sig (signifikan) diperoleh nilai sig $=0,007$ lebih kecil dari nilai probabilitas 0.05 atau nilai $0,007<0,05$ maka Ho diterima dan $\mathrm{Ha}$ ditolak artinya Kompetensi tenaga medis berpengaruh secara positif dan signifikan terhadap kepuasan pasien, adapun hal yang membuat pasien puas karena tenaga kesehatan ikut berpartisipasi melaksanakan pelayanan kepada masyarakat, menyelenggarakan upaya kesehatan yang bersifat menyeluruh, terpadu, merata dapat diterima dan terjangkau oleh masyarakat dengan peran serta aktif masyarakat dan menggunakan responden menjawab tidak puas yaitu 19 orang $(36,5 \%)$

Hasil analisis bivariat dengan menggunakan uji chi-square diperoleh nilai $p$ - value $=0,002(p-$ value $<0,05$ ), artinya Ho ditolak, ini menunjukan bahwa ada pengaruh signifikan antara bukti fisik terhadap kepuasan pasien rawat jalan di Puskesmas Sei Agul Tahun 2019. Hasil pengembangan ilmu pengetahuan dan teknologi tepat guna, dengan biaya yang dapat dipikul oleh pemerintah dan masyarakat luas guna mencapai derajat kesehatan yang optimal, tanpa mengabaikan mutu pelayanan kepada perorangan. Hal ini dapat diartikan bahwa kompetensi tenaga medis memiliki pengaruh yang berarti dalam upaya meningkatkan kepuasan pasien, oleh karena itu tenaga medis sangat perlu untuk berusaha meningkatkan kompetensi yang dimilikinya sehingga kedepannya dapat meningkatkan rasa kepuasan pasien terhadap kompetensi yang dimiliki oleh tenaga medis.

Berdasarkan hasil analisis regresi berganda,empati mempunyai pengaruh yang signifikan terhadap kepuasan pasien rawat jalan di Puskesmas Sei Agul. Berdasarkan hasil pengamatan peneliti terhadap empati yang merupakan perhatian secara individual yang diberikan puskesmas kepada pasien, seperti kemudahan untuk memanfaatkan jasa yang ditawarkan, kemampuan melakukan komunikasi untuk menyampaikan informasi, perhatian pribadi dan memahami kebutuhan para pasien sudah cukup baik. Namun pendapat ini berbeda dengan penelitian yang sudah dilakukan oleh Marmeam, dkk (2017) bahwa hasil regresi variabel empati memperoleh nilai signifikan sebesar 0.317 artinya lebih besar dari taraf signifikan 0,05 sehingga tidak berpengaruh secara signifikan, hal ini menunjukan bahwa Ha ditolak atau berarti tidak ada pengaruh empati terhadap kepuasan pasien rawat jalan. Dengan demikian empati bukan merupakan faktor dominan yang mempengaruhi kepuasan pasien. Berdasarkan pengalaman sehari-hari, ketidakpuasan pasien yang sering ditemukan berkaitan dengan sikap dan perilaku petugas rumah sakit, seperti; keterlambatan pelayanan oleh perawat dan dokter, dokter tertentu sulit ditemui yaitu dokter

\section{PEMBAHASAN}

Berdasarkan hasil uji statistik menggunakan uji chi-square diperoleh nilai $p$ - value $=0,004$ ( $p$ value $<0,05$ ), artinya Ho ditolak, ini menunjukan bahwa ada pengaruh signifikan antara kompetensi terhadap kepuasan pasien rawat jalan di Puskesmas Sei Agul Tahun 2019.

Menurut hasil pengamatan, kompetensi tenaga kesehatan di Puskesmas Sei Agul cukup baik karena tenaga kesehatan dalam menanggapi pasien sangat ramah dan sopan sehingga pasien merasa lebih diperhatikan oleh tenaga kesehatan. Namun masih ditemukan beberapa pegawai yang terlambat dalam menyelesaikan pekerjaan dalam melayani pasien hal ini disebabkan oleh kekurangan SDM. Selain itu, pada indikator keterampilan ditemukan tenaga medis yang tidak selalu mengetahui apa yang di butuhkan pasien seperti menjawab pertanyaan-pertanyaan yang di lontarkan pasien maupun keluarga pasien. Hal ini perlu mendapat perhatian khusus dari pihak puskesmas dengan cara meningkatkan sumber daya manusia semua tenaga kesehatan baik kualitas maupun kuantitas melalui penambahan tenaga sesuai kebutuhan untuk meningkatkan kepuasan pasien.

Hasil penelitian yang dilakukan oleh Jusriani, 
dkk (2016) memperlihatkan bahwa nilai p-value sebesar 0,018, hal ini menunjukan ada hubungan antara kehandalan dengan pasien rawat jalan di Puskesmas Puriala Kecamatan Puriala Kabupaten Konawe. Adapun yang membuat pasien puas terhadap kehandalan karena petugas kesehatan selalu menjelaskan hasil pemeriksaan kepada pasien,kesiapan perawat melayani pasien setiap saat, perawat melaporkan secara detail perubahan pasien kepada dokter pada saat berkunjung. Hal ini perlu ditingkatkan lagi karena kehandalan tenaga kesehatan sangat penting dalam membantu kurang komunikatif dan informatif, perawat yang kurang ramah dan tanggap terhadap kebutuhan pasien, lamanya proses masuk perawatan, aspek pelayanan di puskesmas serta kebersihan, ketertiban, kenyamanan dan keamanan puskesmas. Dengan demikian puskesmas harus menyiapkan petugaspetugas kesehatan yang handal dan profesional dalam menjalankan tugas-tugasnya. proses kesembuhan pasien dengan tepat dan terpercaya sehingga dapat memberikan pelayanan yang bermutu dan memuaskan.

Penelitian ini didukung oleh teori kompetensi yaitu kemampuan, keterampilan petugas, penguasaan terhadap suatu tugas,sikap, dan apresiasi yang diperlukan untuk memuaskan pasien yang berkunjung ke Puskesmas (Sutrisno, 2016).

Berdasarkan hasil pengamatan peneliti bahwa dalam penilaian pasien kehandalan tenaga kesehatan cukup membuat pasien puas hal ini pasien menyatakan bahwa petugas sudah handal disebabkan karena petugasmedis/ dokter di Puskesmas memberikan tindakan layanan yang akurat dalam menangani keluhan pasien dan penyakit yang diderita pasien. Tenaga kesehatan professional dalam menjalankan tugas dan tanggung jawabnya demi untuk melayani siapa saja yang membutuhkan pertolongan.namun ada juga pasien menyatakan kehandalan masih kurang baik karena prosedur pelayanan yang diberikan terlalu berbelit- belit.Maka kehandalan perlu diperhatikan lagi sehingga pasien akan puas dan menaruh kepercayaan akan layanan yang diberikan.

Berdasarkan hasil uji statistik menggunakan uji Chi-Square diperoleh $p$-value $=0,043$ ( $p$-value $<\alpha$ ) maka Ho ditolak, Ha diterima sehingga dapat disimpulkan bahwa ada pengaruh kehandalan terhadap kepuasan pasien di Puskesmas Sei Agul Tahun 2019.

Menurut hasil pengamatan peneliti bahwa dalam penilaian pasien kehandalan tenaga kesehatan cukup membuat pasien puas hal ini pasien menyatakan bahwa petugas sudah handal disebabkan karena petugas medis/ dokter di Puskesmas memberikan tindakan layanan yang akurat dalam menangani keluhan pasien dan penyakit yang diderita pasien. Tenaga kesehatan professional dalam menjalankan tugas dan tanggung jawabnya demi untuk melayani siapa saja yang membutuhkan pertolongan. Begitupun dengan dokter yang akan memeriksa pasien, dokter memeriksa pasien sesuai jadwal yang telah ditentukan, sehingga pasien tidak terlalu lama menunggu saat akan diperiksa namun ada juga pasien menyatakan kehandalan masih kurang baik karena prosedur pelayanan yang diberikan terlalu berbelit-belit tidak sesuai dengan keinginan mereka sehingga pasien lebih memilih puskesmas lain. Maka kehandalan perlu diperhatikan lagi sehingga pasien akan puas dan menaruh kepercayaan akan layanan yang diberikan.

Hasil penelitian yang dilakukan oleh Jusriani, dkk (2016) memperlihatkan bahwa nilai $p$-value sebesar 0,018, hal ini menunjukan ada hubungan antara kehandalan dengan pasien rawat jalan di Puskesmas Puriala Kecamatan Puriala Kabupaten Konawe. Adapun yang membuat pasien puas terhadap kehandalan karena petugas kesehatan selalu menjelaskan hasil pemeriksaan kepada pasien,kesiapan perawat melayani pasien setiap saat, perawat melaporkan secara detail perubahan pasien kepada dokter pada saat berkunjung. Hal ini perlu ditingkatkan lagi karena kehandalan tenaga kesehatan sangat penting dalam membantu proses kesembuhan pasien dengan tepat dan terpercaya sehingga dapat memberikan pelayanan yang bermutu dan memuaskan.

Penelitian ini didukung oleh teori kompetensi yaitu kemampuan, keterampilan petugas, penguasaan terhadap suatu tugas,sikap, dan apresiasi yang diperlukan untuk memuaskan pasien yang berkunjung ke Puskesmas (Sutrisno, 2016).

Berdasarkan hasil pengamatan peneliti bahwa dalam penilaian pasien kehandalan tenaga kesehatan cukup membuat pasien puas hal ini pasien menyatakan bahwa petugas sudah handal disebabkan karena petugasmedis/ dokter di Puskesmas memberikan tindakan layanan yang akurat dalam menangani keluhan pasien dan penyakit yang diderita pasien. Tenaga kesehatan professional dalam menjalankan tugas dan 
tanggung jawabnya demi untuk melayani siapa saja yang membutuhkan pertolongan.namun ada juga pasien menyatakan kehandalan masih kurang baik karena prosedur pelayanan yang diberikan terlalu berbelit- belit.Maka kehandalan perlu diperhatikan lagi sehingga pasien akan puas dan menaruh kepercayaan akan layanan yang diberikan.

Hasil analisis bivariat dengan menggunakan uji chi-square diperoleh nilai $p$ - value $=0,005(p-$ value $<0,05$ ), artinya Ho ditolak, ini menunjukan bahwa ada pengaruh signifikan antara daya tanggap petugas kesehatan terhadap kepuasan pasien rawat jalan di Puskesmas Sei Agul Tahun 2019. Berdasarkan hasil observasi bahwa daya tanggap yang diberikan oleh tenaga kesehatan sudah baik karena kemampuan tenaga kesehatan cepat dalam menaggapi keluhan pasien sehingga pasien merasa puas terhadap daya tanggap yang diberikan tenaga kesehatan dalam menangani keluhan pasien. Pelayanan yang diberikan oleh dokter dan perawat dengan daya tanggap yang baik akan memberikan penanganan yang cepat pula terhadap keluhan pasien sehingga pasien merasa puas terhadap pelayanan yang diberikan.

Hasil penelitian yang dilakukan oleh Andoko dkk (2018), diperoleh nilai $p$-value $=0,000$ memperlihatkan bahwa nilai signifikan $p$ - value < $\alpha=0,005$. Hal ini menunjukan bahwa ada hubungan antara daya tanggap dengan kepuasan pasien di Puskesmas Way Halim Kota Bandar Lampung. Menurut pendapat peneliti memang pasien yang mendapatkan pelayanan di Puskesmas bukan merupakan pasien dengan pelayanan rawat inap, sehingga bagi pasien ada kecenderungan kurang diperhatikan dengan kata lain pasien kurang memperdulikan faktor sarana dan fasilitas penunjang, karena tak semua pasien selalu memanfaatkan sarana penunjang atau bahkan bisa terjadi pasien awam terhadap sarana / kualitas sarana yang dimiliki Puskesmas. Hal ini menunjukan pula bahwa tuntutan pasien yang utama adalah berobat ke Puskesmas dilayani dengan baik dan sembuh dari penyakitnya. Sementara pasien tak terlalu menuntut adanya faktor sarana dan fasilitas penunjang.

Penelitian ini didukung oleh teori daya tanggap (responsiveness) yaitu kesediaan dan kemampuan petugas kesehatan dalam melayani pasien dan memenuhi harapan pasien dalam kecepatan pelayanan (Muninjaya, 2018).

Hal ini menyatatakan persepsi daya tanggap yang perlu ditingkatkan pada pelayanan yang cepat dan tanggap, hal ini sangat penting dalam memberikan pelayanan tenaga kesehatan yang memuaskan pasien, karena pasien sangat membutuhkan pelayanan yang cepat dan tanggap sehingga dapat membuat pasien merasa dilayani dengan baik dan penuh rasa sabar serta tanggap sehingga akan membantu dalam proses penyembuhan

Pengaruh Jaminan Terhadap Kepuasan Pasien Rawat Jalan di Puskesmas Sei Agul Tahun 2019

Hasil analisis bivariat dengan menggunakan uji chi-square diperoleh nilai $p$ - value $=0,109(p-$ value $>0,05$ ), artinya Ho diterima, ini menunjukan bahwa tidak ada pengaruh signifikan antara jaminan petugas kesehatan terhadap kepuasan pasien rawat jalan di Puskesmas Sei Agul Tahun 2019. Berdasarkan hasil observasi bahwa jaminan di Puskesmas Sei Agul kurang baik karena tenaga kesehatan tidak sungguh-sungguh mengobati pasien dengan baik sehingga rasa keyakinan untuk sembuh tidak ada, dan tenaga kesehatan kurang memiliki pengetahuan dan kemampuan memberikan pelayanan kesehatan dengan kepercayaan bebas resiko. Oleh sebab itu dimensi jaminan tenaga kesehatan harus diperbaiki lagi khususnya tenaga kesehatan ketika melayani pasien harus dengan sepenuh hati agar menimbulkan rasa puas ketika berobat di Puskesmas Sei Agul.

Hasil penelitian yang telah dilakukan oleh Rizal dkk (2017), menyatakan bahwa pada analisis uji statistik Chi-square dengan nilai $p$ value $=0,251 \quad(p$-value >0,05). Hal ini menunjukkan bahwa semakin tinggi jaminan yang diberikan, maka semakin meningkatkan kepuasan pasien sehingga tidak ada pengaruh signifikan antara jaminan petugas kesehatan terhadap kepuasan pasien. Artinya jaminan berpengaruh secara langsung, positif dan tidak signifikan terhadap loyalitas pasien melalui kepuasan pasien sebagai variabel mediasi. Penelitian ini membuktikan bahwa kepuasan pasien bukan berperan sebagai variabel mediasi dalam pengaruh kualitas pelayanan terhadap loyalitas pasien.

Namun penelitian ini berbeda dengan penelitian yang telah dilakukan oleh Andoko dkk (2018) menunjukan bahwa hasil uji statistik diperoleh $p$-value $=0,000$ yang berarti $p<\alpha$, maka dapat disimpulkan bahwa ada hubungan antara jaminan dengan kepuasan pasien di Puskesmas Way Halim Kota Bandar Lampung tahun 2018. Berdasarkan hasil observasi peneliti diketahui terdapat responden dengan persepsi jaminan baik 
dan puas hal ini karena diketahui bahwa pada item pernyataan petugas selalu memberi salam dan senyum ketika bertemu dengan pasien, petugas teliti dan terampil dalam melaksanakan tindakan perawatan kepada responden memiliki nilai tertinggi sehingga dapat disimpulkan bahwa pada dimensi jaminan ini responden merasa baik dan menyebabkan puas dan terdapat responden yang mengatakan jaminan tidak baik namun responden puas dan terdapat beberapa responden yang tidak puas terlihat dari petugas memberi perhatian terhadap keluhan yang pasien rasakan. petugas dapat menjawab pertanyaan tentang tindakan pengobatan yang diberikan kepada pasien. Petugas jujur dalam memberikan informasi tentang keadaan pasien.

Penelitian ini didukung oleh teori jaminan (assurance) yaitu kemampuan tenaga kesehatan untuk menimbulkan keyakinan dan kepercayaan terhadap janji-janji yang telah dikemukakan kepada pasien. Jaminan juga berarti bahwa tenaga kesehatan selalu bersikap sopan dan menguasai pengetahuan dan keterampilan yang dibutuhkan untuk menangani setiap pertanyaan dan masalah pasien (Purwoastuti dkk, 2015 ).

Berdasarkan hasil wawancara yang peneliti lakukan dengan responden terdapat responden yang memberi tanggapan bahwa kemampuan dokter dalam menjelaskan penyakit kurang baik karena ketika dokter melakukan pemeriksaan atau pengobatan dokter tidak memberikan penjelasan mengenai penyakit responden, kemudian ketepatan diagnosa yang dilakukan dokter masih belum baik maka perlu kebijakan kepada tenaga kesehatan agar memperbaiki kinerja yang kurang baik terutama dalam hal pelayanan terhadap pasien rawat jalan.

Hasil analisis bivariat dengan menggunakan uji chi-square diperoleh nilai $p$ - value $=0,000(p$ value $<0,05$ ), artinya Ho ditolak, ini menunjukan bahwa ada pengaruh signifikan antara empati petugas kesehatan terhadap kepuasan pasien rawat jalan di Puskesmas Sei Agul Tahun 2019. Berdasarkan hasil pengamatan ditemukan bahwa empati di puskesmas cukup baik karena adanya perhatian yang khusus oleh tenaga kesehatan kepada pasien serta tenaga kesehatan sangat ramah kepada pasien ketika pasien berkunjung ke puskesmas namun dokter serta perawat kurang meluangkan waktu khusus untuk berkomunikasi kepada pasien. Maka perlu adanya komunikasi yang baik antara pasien dan tenaga kesehatan.

Hasil penelitian yang telah dilakukan oleh Rizal dkk (2017) yang menyatakan bahwa pada analisis uji statistik Chi-square memperlihatkan hasil $p$-value $=0,008(p$-value $<0,05)$. Hal ini menunjukan bahwa ada pengaruh empati terhadap kepuasan pasien peserta BPJS. Hasil penelitian yang dilakukan oleh Mernawati dkk (2016), memperlihatkan nilai $p$-value 0,03 $<0,05$. Hal ini menunjukan ada hubungan antara empati dengan kepuasan pasien di Puskesmas Lamper Tengah. Penelitian ini tidak membuktikan bahwa kepuasan pasien berperan sebagai variabel mediasi dalam pengaruh kualitas pelayanan terhadap loyalitas pelanggan. Mencermati perkembangan pelayanan kesehatan saat ini, dengan adanya kemudahan yang diperoleh dari rumah sakit swasta yang sangat ramah, menimbulkan efek yang positif pada nilai yang dirasakan pasien.

Namun hasil penelitian ini berbeda dengan penelitian Marmeam dkk (2018) diperoleh nilai $p$ value $=0,123$ ( $p$-value $>0,05)$. Hal ini menunjukan bahwa tidak ada hubungan yang signifikan antara empati terhadap kepuasan pasien rawat jalan RSUD Dr. Zubir Mahmud Kabupaten Aceh Timur. ketidakpuasan pasien yang sering ditemukan berkaitan dengan sikap dan perilaku petugas rumah sakit dokter kurang komunikatif dan informatif, perawat yang kurang ramah.

Penelitian ini didukung oleh teori empati (empathy) yaitu perhatian yang diberikan puskesmas terhadap pasien dan keluarganya seperti kemampuan berkomunikasi dan perhatian yang tinggi dari petugas kesehatan (Tribowo, 2013).

Hal ini menyatakan bahwa kepedulian kepada pasien harus lebih diperhatikan lagi karena pelayanan kesehatan yang baik terhadap pasien akan meningkatkan kepuasan pasien terhadap pelayanan yang didapatkannya. Dengan memberikan kesempatan kepada pasien untuk bertanya dan menjawab pertanyaannya dengan jelas dan memperhatikan kebutuhan pasien. Berdasarkan hasil wawancara diketahui bahwa banyak responden yang beranggapan kurang baik terhadap empati pegawai puskesmas diantaranya mengenai kurangnya perhatian petugas secara khusus kepada pasien, petugas tidak peduli dengan kondisi pasien, dokter jarang meluangkan waktu untuk berkomunikasi yang bai kepada pasien dan tidak mempunyai waktu untuk berkonsultasi dengan keluarga pasien.

Hasil analisis bivariat dengan menggunakan uji chi-square diperoleh nilai $p$ - value $=0,002(p-$ value $<0,05$ ), artinya Ho ditolak, ini menunjukan bahwa ada pengaruh signifikan antara bukti fisik 
puskesmas terhadap kepuasan pasien rawat jalan di Puskesmas Sei Agul Tahun 2019. Berdasarkan hasil pengamatan yang dilakukan oleh peneliti ditemukan bahwa bukti fisik cukup baik dan puas namun ada juga yang masih belum puas terhadap fasilitas yang ada di puskesmas tersebut, hal ini menurut pendapat peneliti petugas memberi informasi tentang administrasi yang berlaku bagi pasien dan petugas selalu menjaga kerapian dan penampilannya sehingga membuat persepsi tentang bukti fisik adalah baik dan ada juga berpendapat terdapat responden mengatakan bukti fisik baik namun tidak puas hal ini dikarenakan bahwa petugas kurang menjaga kebersihan dan kerapihan ruangan yang ditempati dan ada juga yang berpendapat jumlah bangku yang tersedia di dalam puskesmas kurang lengkap sehingga menyebabkan ketika pasien mengantri terdapat beberapa pasien yang harus rela berdiri untuk menunggu antrian. Hal ini perlu diperhatikan oleh pihak puskesmas terhadap kelengkapan fasilitas dan kebersihan di puskesmas sehingga menimbulkan kenyaman dan kepuasan ketika berobat di puskesmas.

Hasil penelitian yang dilakukan oleh Hasibuan dkk (2019) di RSUD DR. Djoelham Binjai yang memperlihatkan nilai $p$-value $=0,007$ ( $p$-value $<0,05$ ), hal ini menunjukan bahwa ada pengaruh yang signifikan terhadap kepuasan pasien rawat jalan di RSUD Dr. RM Djoelham Binjai. Adapun hal yang membuat pasien puas terhadap bukti fisik seperti area parkir yang cukup luas, terdapat tempat ibadah yang nyaman dan pelayanan makan minum (kantin) yang lengkap dan terjamin kebersihannya. Bila pasien merasa nyaman dengan layanan yang ada di rumah sakit maka kenyamanan akan mempengaruhi kepuasan pasien sehingga mendorong pasien untuk datang berobat kembali.

Penelitian ini didukung oleh teori Parasuraman mengenai bukti fisik yang merupakan wujud kenyataan secara fisik yang meliputi penampilan dan kelengkapan fasilitas fisik seperti ruangan front office yang nyaman, tersedianya tempat parkir, kebersihan, kerapian petugas kesehatan (Purwoastuti dkk, 2015).

Hal ini menunjukkan bahwa ada pengaruh antara bukti fisik dengan kepuasan pasien. Responden pada penelitian ini yang persepsi tidak baik cenderung tidak puas karena ruang tunggu pasien yang terbatas membuat kondisi ruang tunggu sangat sesak dan padat. Hal ini membuat beberapa pasien harus menunggu terlalu lama dan berdiri serta ketidaknyaman ruangan.
Berdasarkan hasil analisis regresi beganda, kompetensi tidak mempunyai pengaruh yang signifikan terhadap kepuasan pasien rawat jalan di Puskesmas Sei Agul. Berdasarkan hasil observasi, kompetensi tenaga kesehatan di Puskesmas Sei Agul cukup baik karena tenaga kesehatan dalam menanggapi pasien sangat ramah dan sopan sehingga pasien merasa lebih diperhatikan oleh tenaga kesehatan namun penelitian ini berbeda dengan penelitian yang dilakukan oleh Rensi (2019) yang menunjukan hasil analisis diperoleh nilai sig (signifikan) diperoleh nilai sig $=0,007$ lebih kecil dari nilai probabilitas 0.05 atau nilai $0,007<0,05$ maka $\mathrm{Ho}$ diterima dan $\mathrm{Ha}$ ditolak artinya Kompetensi tenaga medis berpengaruh secara positif dan signifikan terhadap kepuasan pasien, adapun hal yang membuat pasien puas karena tenaga kesehatan ikut berpartisipasi melaksanakan pelayanan kepada masyarakat, menyelenggarakan upaya kesehatan yang bersifat menyeluruh, terpadu, merata dapat diterima dan terjangkau oleh masyarakat dengan peran serta aktif masyarakat dan menggunakan hasil pengembangan ilmu pengetahuan dan teknologi tepat guna, dengan biaya yang dapat dipikul oleh pemerintah dan masyarakat luas guna mencapai derajat kesehatan yang optimal, tanpa mengabaikan mutu pelayanan kepada perorangan. Hal ini dapat diartikan bahwa kompetensi tenaga medis memiliki pengaruh yang berarti dalam upaya meningkatkan kepuasan pasien, oleh karena itu tenaga medis sangat perlu untuk berusaha meningkatkan kompetensi yang dimilikinya sehingga kedepannya dapat meningkatkan rasa kepuasan pasien terhadap kompetensi yang dimiliki oleh tenaga medis.

Berdasarkan hasil analisis regresi berganda,empati mempunyai pengaruh yang signifikan terhadap kepuasan pasien rawat jalan di Puskesmas Sei Agul. Berdasarkan hasil pengamatan peneliti terhadap empati yang merupakan perhatian secara individual yang diberikan puskesmas kepada pasien, seperti kemudahan untuk memanfaatkan jasa yang ditawarkan, kemampuan melakukan komunikasi untuk menyampaikan informasi, perhatian pribadi dan memahami kebutuhan para pasien sudah cukup baik. Namun penelitian ini berbeda dengan penelitian yang dilakukan oleh Marmeam, dkk (2017) bahwa uji regresi variabel empati memperoleh nilai signifikan sebesar 0.317 artinya lebih besar dari taraf signifikan 0,05 sehingga tidak berpengaruh secara signifikan, hal ini 
menunjukan bahwa Ha ditolak atau berarti tidak ada pengaruh empati terhadap kepuasan pasien rawat jalan. Dengan demikian empati bukan merupakan faktor dominan yang mempengaruhi kepuasan pasien. Berdasarkan pengalaman sehari-hari, ketidakpuasan pasien yang sering ditemukan berkaitan dengan sikap dan perilaku petugas rumah sakit, seperti; keterlambatan pelayanan oleh perawat dan dokter, dokter tertentu sulit ditemui yaitu dokter kurang komunikatif dan informatif, perawat yang kurang ramah dan tanggap terhadap kebutuhan pasien, lamanya proses masuk perawatan, aspek pelayanan di puskesmas serta kebersihan, ketertiban, kenyamanan dan keamanan puskesmas. Dengan demikian puskesmas harus menyiapkan petugas-petugas kesehatan yang handal dan profesional dalam menjalankan tugastugasnya.

\section{KESIMPULAN DAN SARAN}

Berdasarkan penelitian yang telah dilakukan dapat disimpulkan sebagai berikut: Adanya pengaruh kompetensi terhadap kepuasan pasien rawat jalan di Puskesmas Sei Agul Tahun 2019 dengan nilai $p=0,015$.Ada pengaruh kualitas petugas kesehatan berdasarkan kehandalan terhadap kepuasan pasien rawat jalan di Puskesmas Sei Agul Tahun 2019 dengan nilai $p=$ 0,043 . Ada pengaruh kualitas petugas kesehatan berdasarkan daya tanggap terhadap kepuasan pasien rawat jalan di Puskesmas Sei Agul Tahun 2019 dengan nilai $p=0,005$. Tidak ada pengaruh kualitas petugas kesehatan berdasarkan jaminan terhadap kepuasan pasien rawat jalan di Puskesmas Sei Agul Tahun 2019 dengan nilai $p=$ 0,109 . Ada pengaruh kualitas petugas kesehatan berdasarkan empati terhadap kepuasan pasien rawat jalan di Puskesmas Sei Agul Tahun 2019 dengan nilai $p=0,000$. Ada pengaruh kualitas petugas kesehatan berdasarkan bukti fisik terhadap kepuasan pasien rawat jalan di Puskesmas Sei Agul Tahun 2019 dengan nilai $p=$ 0,002 . Dari hasil uji regresi maka empati yang lebih berpengaruh terhadap kepuasan pasien rawat jalan di Puskesmas Sei Agul dengan nilai $p$ $=0,000$. Saran yang dapat penulis simpulkan dari hasil penelitian ini yaitu Diharapkan kepada pihak Puskesmas Sei Agul agar meningkatkan kompetensi dan kualitas petugas kesehatan.

\section{REFERENSI}

1. Andoko, Norman, H \& Novalina, D. 2018,
Hubungan Mutu Pelayanan Terhadap Tingkat Kepuasan Pasien Rawat Jalan Di Puskesmas Way Halim Kota Bandar Lampung Tahun 2018. Holistik Jurnal Kesehatan, Vol. 12, No. 2, hh. 92-102.

2. Eninurkhayatun, B. Suryoputro, A. Fatmasari, YE. 2017, Analisis Tingkat Kepuasan Pasien Terhadap Kualitas Pelayanan Rawat Jalan Di Puskesmas Duren dan PusKkesmas Bergas Kabupaten Semarang Tahun 2017. Jurnal Kesehatan Masyarakat, Vol. 5, No. 4, hh.33-42.

3. Fahlevi, IM 2017, Pengaruh Kompetensi Petugas Terhadap Kinerja Pelayanan Kesehatan Di Puskesmas Peureumeue Kabupaten Aceh Barat.

4. Hasibuan, AS. Zulfendri \& Aulia, D. 2019, Pengaruh Kualitas Pelayanan Dengan Kepuasan Pasien Di Rawat Jalan Penyakit Dalam RSUD DR. DJOELHAM Binjai. Jurnal Kesmas Jambi (JKMJ), Vol. 3, No 1, hh 24- 30.

5. Jusriani, Junaid, Lisnawaty. 2016.Hubungan Mutu Pelayanan Kesehatan Dengan Kepuasan Pasien Rawat Jalan Puskesmas Puriala Kecamatan Puriala Kabupaten Konawe. Jurnal Kesehatan Masyarakat. Universitas Halu Oleo.

6. Kemenkes, RI. 2015. Laporan Akuntabilitas Kinerja Kementrian Kesehatan Tahun 2014.

7. Marmeam, Utami, NT. Simanjorang, 2018. Faktor-faktor Yang Mempengaruhi Pasien Rawat Jalan Di Rumah Sakit Umum Daerah Dr. Zubir Mahmud Kabupaten Aceh Timur. Jurnal JUMANTIK. Vol 3 No 2.

8. Marwansyah, 2016. Manajemen Sumber Daya Manusia, edk 2, Alfabeta, Bandung.

9. Muninjaya , A.A. Gde. 2018. Manajemen Mutu Pelayanan Kesehatan. Jakarta: Penerbit Buku Kedokteran EGC.

10. Notoatmodjo, Soekidjo. 2012. Metodologi Penelitian Kesehatan. edk 1, Rineka Cipta, Jakarta.

11. Pohan, Imbalo S. 2018. Jaminan Mutu Layanan Kesehatan. Jakarta: Penerbit Buku Kedokteran EGC.

12. Profil Puskesmas Sei Agul Tahun 2108

13. Purwoastuti, E 2015. Mutu Pelayanan Kesehatan dan Kebidanan. Yogyakarta: Pustaka Bary Press. 
14. Raditio, A, Th 2014, Analisis Pengaruh Kualitas Pelayanan dan Fasilitas Kesehatan Terhadap Kepuasan Pasien Puskesmas. Jurnal Ilmu Manajemen, Vol. 11, No. 2, hh. 1-26.

15. Rensi, Nike. 2019. Pengaruh Kompetensi Tenaga Medis Dan Pelayanan Kesehatan Terhadap Kepuasan Pasien Pada Puskesmas Poncowati Kecamatan Terbanggi Kabupaten Lampung Tengah. Jurnal Simplex, Vo. 2, No. 2, hh. 141-151

16. Rizal, R. Suardi, M. \& Yulihasri. 2017. Pengaruh Kualitas Pelayanan dan Kepuasan Pasien Peserta BPJS Kesehatan Sebagai Mediasi Terhadap Loyalitas Pasien, Jurnal Sains Farmasi \& Klinis, Vo. 3, No. 2, hh. 108-114.

17. Wibowo, 2014. Manajemen Kinerja, Edk 4, Rajawali Pers, Jakarta. 